\title{
URGENSI PENDIDIKAN KARAKTER DALAM MEMBENTUK AKHLAK PESERTA DIDIK
}

Received: 18-04-2020
Revised: 06-05-2020
Accepted: $12-07-2020$

\section{Rony1, Siti Ainun Jariyah ${ }^{2}$}

Sekolah Tinggi Agama Islam Al-Fitrah Surabaya, Institut Pesantren KH. Abdul Chalim Pacet Mojokerto ${ }^{1,2}$

Email: rony99arka@gmail.com, Sitiainunjariyah99@gmail.com

Keywords: Islamic Character Education, Student, Urgency

\begin{tabular}{l}
\hline Kata kunci: \\
Pendidikan \\
Karakter, Urgensi, \\
Peserta didik \\
\hline
\end{tabular}

\begin{abstract}
Character education in Indonesia needs to be instilled from an early age, given the decline in morality of students in the era of globalization. Morality is an element that shows the quality of people's lives. Religious people assume that religion always teaches its followers to do good and prohibits them from doing wrong. Meanwhile, humanists assume that a person's morality is seen from how someone obeys the values and norms in society. Cultivating character education through three stages, namely internalization and externalization. The three processes of planting can show positive results, of course, the character of the students is also good. However, if the three processes are not optimal, the results obtained by students are also not optimal. The internalization process becomes the basic process or foundation for character education of students, where the family forms the basis of character in the form of character recognition to students. And externalization is the next process of internalization where this process is filled by education staff, peers, social media.
\end{abstract}

Abstrak
Pendidikan karakter di Indonesia dirasa perlu ditanamkan sejak
dini, mengingat merosotnya moralitas peserta didik di era
globalisasi. Moralitas menjadi satu unsur yang menunjukkan
kualitas bagi kehidupan masyarakat. Orang-orang beragama
memiliki asumsi bahwa agama selalu mengajarkan pengikutnya
untuk berbuat baik dan melarangnya melakukan kesalahan.
Sedangkan budayawan berasumsi moralitas seseorang diliat dari
sebagaimana seseorang mematuhi nilai dan norma di masyarakat.
Penanaman pendidikan karakter melalui tiga tahap yaitu
internalisasi dan eksternalisasi. Dalam ketiga proses penanaman
tersebut bisa menunjukkan hasil positif tentunya karakter peserta
didik juga baik. Akan tetapi jika dari tiga proses tidaklah maksimal
makan hasil yang didapat peserta didik juga tidak maksimal. Proses
internalisasi menjadi proses dasar atau pondasi bagi pendidikan
karakter peserta didik, dimana keluarga menjadi pembentuk dasar
karakter berupa pengenalan karakter kepada peserta didik. Dan
eksternalisasi merupakan proses selanjutnya dari internalisasi
dimana proses ini di isi oleh tenaga pendidikan, teman sebaya,
media sosial.


Rony, Siti Ainun Jariyah

\section{PENDAHULUAN}

Masalah pendidikan di Indonesia sering kita ketahui sangat kompleks dengan permasalahan-permasalahan seputar karakter dan kepribadian peserta didik sehingga menjadi perhatian kita bersama, krisis karakter peserta didik atau moralitas ditandai dengan adanya tawuraan antar pelajar yang semakin tahun semakin meningkat, penyelahgunaan obat-obatan terlarang (narkoba), dan pergaulan bebas sudah tidak asing lagi sering kita jumpai. Adapun beberapa krisis pendidikan akhlak atau moral yang sudah nyata sering kita jumpai yaitu kurangnya rasa hormat atau sopan santun terhadap guru (pendidik) atau orang yang lebih tua darinya. Beberapa persoalan diatas sudah tidak bisa dihindari lagi karena dengan berkembang nya zaman dari masyarakat yang dulunya industrialis menjadi masyarakat yang serba informatif ${ }^{1}$.

Oleh karena itu untuk menyikapi persoalan permasalahan diatas pendidikan karakter dalam membentuk akhlak peserta didik sangatlah penting, karena pendidikan sendiri ialah merupakan aset atau investasi bangsa yang terpenting dan sangat berharga. Karena dalam sebuah pendidikan sendiri tidak hanya untuk mengembangkan ranah konitif peserta didik saja, tetapi sebuah pendidikan juga harus mengembangkan ranah afektif dan psikomotorik untuk mengarahkan peserta didik menjadi kepribadian yang berkarakter yang sesuai dengan cerminan bangsa²

Tujuan pendidikan karakter sendiri yang diharapkan pemerintah Indonesia ialah yang pertama, agar dapat mengembangkan hati nurani atau kolbu pada diri peserta didik agar memiliki nilai-nilai karakter budaya dan mempunyai karakter bangsa pada dirinya, yang kedua dapat menanamkan nilai-nilai bangsa atau budaya yang religious terhadap peserta didik agar dapat mengembangkan kebiasaan peserta didik dengan perilaku yang terpuji yang sejalan dengan nilai-nilai

1 Muhammad Ridwan, 'Konsep Tarbiyah, Ta'lim Dan Ta'dib Dalam Al-Qur'an', Nazhruna: Jurnal Pendidikan Islam 1, no. 1 (16 August 2018): 35-57, https://doi.org/10.31538/nzh.v1i1.41.

2 Muhammad Amri, Saharuddin Saharuddin, and La Ode Ismail Ahmad, 'The Implementation of Islamic Education: The Process of Instilling Akhlakul Karimah (Noble Characters) for Madrasah Tsanawiyah Students', Tadris: Jurnal Keguruan Dan Ilmu Tarbiyah 4, no. 1 (28 June 2019): 117-25, https://doi.org/10.24042/tadris.v4i1.4070. 
universal $^{3}$. Yang ketiga menanamkan rasa tanggung jawab terhadap peserta didik dan menanamkan jiwa-jiwa kepemimpinan untuk menjadi generasi penerus bangsa,yang keempat menumbuhkan pada diri peserta didik agar menjadi maanusia yang mandiri, kreatif dan dapat berwawasan kebangsaan yang luas.yang kelima dapat menciptakan suasana sekolah menjadi lingkungan yang aman, penuh dengan kreatifitas dan persahabatan jujur dan serta rasa kebangsaan yang tinggi dan mempunyai kekuatan. ${ }^{4}$

Fungsi dari pendidikan karakter sendiri yaitu membentuk dan mengembangkann potensi peserta didik agar dapat berfikir secara baik dan dapat berahati-hati dalam berprilaku, dan dengan adanya implementai pendidikan karakter dalam membentuk akhlak supaya dapat memperkuat dan memperbaiki peran kesatuan pendidikan,keluarga dan masyarakat agar dapat ikut berpartisipasi dalam mengembangkann potensi Negara yang maju dan,sejahtera tanpa melupakan etika kesopanan budaya masing-masing 5 .

Maka dengan adanya Pendidikan karakter sendiri menjadi salah satu jawaban permasalah-permasalahan di atas, dan sebagai penyelengara sebuah pendidikan sekolah diharapkan bisa menjadi visi misi pendidikan yang berkarakter tersebut. Salah satu mata pelajaran yang dilaksanakan dalam pendidikan karakter yaitu pendidikan agama islam (PAI), karena dalam peran pendidikan agama ialah suatu pendidikan yang strategis dalam mewujudkan sebuah karakter pada diri peserta didik di indonesia.

Dengan adanya pendidikan agama islam di harapkan bisa mencetak generasigenerasi selanjutnya yang lebih taqwa dan selalu berupaya dalam menyempurnakan iman nya, berakhlak mulia semua etika, budi pengerti dan moral agar dapat mewujudkan dari sebuah pendidikan. Karena manusia yang memiliki

${ }^{3}$ Nana Herdiana Abdurrahman, 'Character Education in Islamic Boarding SchoolBased Sma Amanah', Jurnal Pendidikan Islam 2, no. 2 (21 June 2016): 287-305, https://doi.org/10.15575/jpi.v2i2.791.

4 Binti Maunah, 'Implementasi Pendidikan Karakter Dalam Pembentukan Kepribadian Holistik Siswa', Jurnal Pendidikan Karakter, no. 1 (2016): 90-101, https://doi.org/10.21831/jpk.v0i1.8615.

${ }^{5}$ Hasan Baharun and Rohmatul Ummah, 'Strengthening Students' Character in Akhlaq Subject Through Problem Based Learning Model', Tadris: Jurnal Keguruan Dan Ilmu Tarbiyah 3, no. 1 (29 June 2018): 21-30, https:/ / doi.org/10.24042/tadris.v3i1.2205. 
Rony, Siti Ainun Jariyah

sifat-sifat diatas diharapkan dapat tangguh dalam menghadapi semua hambatan dan tantangan dalam lingkup masyarakat kecil maupun besar.

Dalam dunia pendidikan sendiri antara pendidik dan peserta didik tidak hanya mentransfer ilmu saja akan tetapi dapat membentuk atau mengubah sebuah karakter atau watak seseorang untuk menjadi lebih baik lagi. Seperti, lebih bisa menghormati yang lebih tua dari nya, lebih sopan dalam berprilaku dalam kehidupan sehari-hari, karena dalam pendidikan karakter itu sendiri dapat membentuk akhlak peserta didik jauh lebih baik lagi untuk menjadi salah satu yang diharapkan menjadi penopanng dari perilaku individu itu sendiri ${ }^{6}$.

Dalam islam sendiri yang sudah disebutkan di hadits imam at-tirmidzi ialah yang artinya.." .orang mukmin yang paling sempurna imannya adalah yang paling baik akhlaknya" dalam isi hadist itu sudah dapat dipahami bahwasanya karakter dan akhlak mempuyai kedudukan yang sangat penting dan fungsi untuk memandu dalam kehidupan sehari-hari karena tidak akan sempurna iman manusia tanpa dilandasi dengan akhak yang baik. Karena dengan sesunggunya sumber utama dari sebuah pembelajaran itu sendiri ialah dari al-qur'an dan hadist, seperti ayat yang sudah tertera sebagai berikut: "bacalah dengan menyebut nama tuhanmu yang menciptakan manusia dari segumpal darah" (Al- Alaq 1-3).

Begitupun dengan proses belajar mengajar sendiri yang diturunkan oleh Allah kepada Nabi Muhammad SAW, dengan melalui metode membaca yang melalui lewat malaikat Jiblil, yaitu Allah mengiginkan nabi Muhamad SAW membacakan apapun yang di sampaikan oleh malaikat Jibril. Para ulama' tafsir pun melihat dan berpendapat bahwa kalimat kata kerja yang ada pada fiil amar yaitu Iqro' yang artinya "bacalah" pada ayat pertama tidak dapat maf'ul nya atau "objek"nya, hal ini ditunjukan bahwa yang di baca mempunyai arti yang sanagat luas. Yaitu tidak hanya membaca saja dengan tersurat akan tetapi dengan membaca

${ }^{6}$ Muhammad Anas Ma'arif and Muhammad Husnur Rofiq, 'The Model of Character Teacher: Phenomenology at Daruttaqwa Gresik Islamic Boarding School', Attarbiyah: Journal of Islamic Culture and Education 3, no. 2 (2 January 2019): 131-52, https://doi.org/10.18326/attarbiyah.v3i2.131-152; Muhammad Anas Ma`arif and Ibnu Rusydi, 'IMPLEMENTASI PENDIDIKAN HOLISTIK DI PONDOK PESANTREN AMANATUL UMMAH MOJOKERTO', EDUKASI: Jurnal Penelitian Pendidikan Agama Dan Keagamaan 18, no. 1 (27 April 2020), https://doi.org/10.32729/edukasi.v18i1.598.

Vol.1, No.1, July 2020, 
Tafkir: Interdisciplinary Journal of Islamic Education

Vol.1, No.1, July 2020, , DOI:

Hal: 79-100, E-ISSN 2723-4975

yang tersirat dan tidak tertulis, dalam artian bahwa membaca itu juga termasuk dalam mengamati,meneliti,mengobservasi, dan mengumpulkan sebuah informasi.7

\section{PEMBAHASAN}

\section{Implementasi Pendidikan Karakter}

Menurut kamus besar bahasa Indonesia (KBBI) implementasi dapat diartikan sebagai suatu pelaksanaan atau penerapan, kata implementasi sendiri yang berasal dari b.inggris "to implement" yang artinya mengimplementasikan, sedangkan kata implimentasi sendiri yaitu suatu tindakan atau sebuah pelaksanaan atau rencana yang sudah tersusun secara rinci, menurut Browne dan Wildavsky beliau mengemukakan bahwa implementasi ialah suatu aktifitas peluasan yang saling menyesuaikan. Pendapat ini juga di kemukakan oleh Mclaughin bahwa implementasi ialah aktifitas yang saling menyesuaikan. Sedangkan menurut Schubert (dalam Nurdin dan Usman beliau mengemukakan bahwa sejatinya implementasi itu suatu sistem yang rekayasa. ${ }^{8}$

Menurut pemaparan diatas dapat diketahui bahwa implementasi ialah sebuah aktifitas yang bermuara dengan adanya suatu mekanisme atau sistem,sebuah aksi dan tindakan. Mekanisme sendiri berarti bahwa sebuah implementasi tidak hanya sekedar aktifitas saja akan tetapi implementasi juga ialah sebuah aktifitas yang sudah terencana dan sudah dilakukan dengan sungguh-sungguh dengan mengunakan acuan yang berdasarkan norma-norma tertentu utuk mencapai sebuah tujuan kegiatan. Maka dapat disimpulkan bahwa implementasi tidak dapat berdiri sendiri akann tetapi dengan dipengaruhi dengan objek selanjutnya , yaitu sebuah kurikulum. ${ }^{9}$

Pendidikan karakter ialah suatu bentuk kegiatan manusia yang dimana terdapat di dalam nya suatu tindakan yang mendidik bagi peserta didik

${ }^{7}$ Muhammad Anas Ma`arif, 'Pendidikan Islam Dan Tantangan Modernitas (Input, Proses Dan Output Pendidikan Di Madrasah)', Nidhomul Haq : Jurnal Manajemen Pendidikan Islam 1, no. 2 (2016): 47-58, https:// doi.org/10.31538/ndh.v1i2.1.

8 Workneh, 'IMPLEMENTASI PENDIDIKAN KARAKTER SISWA DI SMP ISLAM AL-AZHAR 18 KOTA SALATIGA', Вестник Росздравнадзора 6 (2017): 5-9.

${ }^{9}$ Workneh. 
sehingga dapat diperuntukan bagi generasi selanjutnya. Pendidikan karakter disekolah dimulai dari seorang pendidik dimana seorang pedidik berprilaku yang mencerminkan perilaku yang baik, sehingga segala sesuatu yang dilakukan oleh pendidik dapat mempengaruhi karakter peserta didiknya, pendidik membantu membenntuk watak peserta didik dengan cara keteladanan bagaimana perilaku guru setiap hari di sekolah, dengan cara pendidik berbicara atau berprilaku yang baik, atau saat pendidik menyampaikan materi di dalam klz, bagaimana cara pendidik bertoleransi dan berbagai macam lainya yang dilakukan di sekolah dari mulai keterbiasaan hal terkecil.

Karakter sendiri sering dimaknai dengan cara berprilaku yang khas pada diri seorang individu dan cara berfikir, baik lingkup keluarga,sosial,dan Negara. Dapat dikatakan sebagai individu berkarakter yang baik apabila dia dapat membuat keputusan dan bisa mempertanggung jawabkan baik atau kurang baiknya keputusan tersebut. Karena karakte sendiri dianggap sebagai nilai-nilai perilaku bagi manusia yang berhubungan dengan yang maha ESA, lingkungan,terhadap manusia.serta pada dirinya sendiri seperti sikap,perkataan,etika dan budaya ${ }^{10}$.

Istilah dari karakter sendiri sering dihubungkan dengan nilai akhlak, etika dan nilai-nilai moral yang positif, maka dari itu pendidikan karakter secara luas diartikan sebagai pendidikan yang dapat mengembangkan nilainilai budaya dalam diri peserta didik sehingga dapat menerapkan nilai-nilai tersebut dalam diri peserta didik sehingga dapat menjadi anggota masyarakat yang religious,nasiomalis dan kreatif. ${ }^{11}$

Bagian pendidikan karakter dari integral dari seluruh tatanan yang ada dalam pendidikan ssistem nasional, maka harus dikembangkan dan

10 Ali Miftakhu Rosyad and Muhammad Anas Maarif, 'Paradigma Pendidikan Demokrasi Dan Pendidikan Islam Dalam Menghadapi Tantangan Globalisasi Di Indonesia', Nazhruna: Jurnal Pendidikan Islam 3, no. 1 (7 February 2020): 75-99, https://doi.org/10.31538/nzh.v3i1.491.

${ }^{11}$ Nur Ainiyah, 'Pembentukan Karakter Melalui Pendidikan Agama Islam' 13, no. 1 (2013): 25-38. 
dilaksanakan dengan cara sistemik dan holistik yang dalam tiga pilar nasional pendidikan karakter. Yaitu: 1. Satuan pendidikan yang meliputi "sekolah,perguruan tinggi,satuan pendidikan nonformal" 2. Keluarga, yang meliputi "keluarga luas dan keluarga inti" 3. Masyarakat, yang meliputi "komunitas,dan keluarga tunggal". Maka dalam hal ini konsistens dalam sebuah konsep tanggung jawab pendidikan nasional yang berada dalam keluarga, sekolah dan masyarakat, karena setiap pilar terdapat suatu entitass sebuah pendidikan yang sudah mengembangkann nilai-nilai, yang meliputi nilai-nilai "nilai instrument,ideal dan nilai praktis". Karena melalui proses campur tangan antar elemen pendidikan dengan kehidupan dunia itu sendiri. ${ }^{12}$

Pendidikan karakter sendiri tersusun dari 3 bagian yaitu ; 1 . Pengetahuan moral, 2.perasaan moral dan 3. Perilaku moral. Karakter yang baik memerlukan pengetahuan tentang moral, bagaimana cara sikap sopan santun dan bisa menghormati orang yang lebih tua darinya, keingginan untuk selalu dapat melakukan kebaikan, berbuat kebaikan terhadap orang lain, seperti membantu orang kesusahan dan menolong orang yang membutuhkan bantuan darinya. ${ }^{13}$

Maka dari itu pendidikan karakter menjadi salah satu akses yang tepat dalam sebuah pelaksanaan character building bagi setiap generasi muda,generasi penerus yang berilmu pengetahuan yang tinggi dan sudah dibekali iman dan takwa terhadap TUHAN YANG MAHA ESA, yang berakhlak mulia mampu bercakap serta kreatif dalam menjadi warga yang bertanggung jawab dan mempuyai sikap yang demokratif. ${ }^{14}$

12 Mujahidah Implementasi and Teori Ekologi, ‘IMPLEMENTASI TEORI EKOLOGI BRONFENBRENNER DALAM MEMBANGUN PENDIDIKAN KARAKTER YANG BERKUALITAS Mujahidah 1' IXX, no. 2 (2015): 171-85.

13 Muhammad Ali Ramdhani, 'Lingkungan Pendidikan Dalam Implementasi Pendidikan Karakter', 2013, 28-37.

${ }^{14}$ Ainiyah, 'Pembentukan Karakter Melalui Pendidikan Agama Islam'. 
Implementasi pendidikan karakter bangsa sendiri bertujuan agar peserta didik dapat mengembangkan karakter mereka masing-masing secara individu agar dapat mampu mewujudkan nilai-nilai luhur yang ada dalam pancasila, seperti.: agar dapat memperkuat dan membangun karakter bangsa yang berjiwa multikultural, menanamkan dan mengembangkan potensi dasar pada diri peserta didik agar berhati baik, dan dapat meningkatkan peradapan dalam bangsa yang kompetitis dalam peradapan dunia.

Semua ini mengacu pada peraturan perundang-undangan yang sudah berlaku dan sudah diyatakan dalam konsep naskah dalam strategi implementasi pendidikan budaya dan karakter pada bangsa di tingkat SMA, untuk menanamkan nilai karakter dan budaya pada diri peserta didik sendiri dapat dilakukan melalui integrasi yang ada dalam mata pelajaran, budaya pada sekolah, dan adanya pengembangan diri. Berhubungan dengan paparan diatas untuk merealisasikanya dengan adanya pendidikan budaya dan karakter bangsa di SMA,perlu adanya dilakukan pendekatan secara sistematis dan integratif dengan cara bekerja sama dengan seluruh pendukung, baik semua yang ada di sekolah, rumah (keluarga), dan masyarakat.

Pendidikan karakter sendiri sering di definisikan sebagai usaha yang dapat mempengaruhi karakter peserta didik, maka diadanya implementasi pendidikan karakter dalam membentuk akhlak peserta didik agar menjadi lebih baik dan semua dapat diawali dengan mengubah karakter peserta didik dan menanamkan nilai-nilai positif pada diri peserta didik, karna pada dasarnya pendidikan karakter sendiri mengandung 3 (tiga) unsur, yaitu: 1 . Mengetahui dalam hal kebaikan. 2.selalu mencintai dalam hal kebaikan. 3. Dan selalu melakukan kebaikan.

Dalam pendidikan karakter sendiri peserta didik tidak diajarkan untuk hanya mengetahui dan mengenal mana perbuatan baik dan perbuatan kurang baik, akan tetapi peserta didik dalam pendidikan karakter diajarkan mananamkan kebiasaan yang baik sehingga peserta didik dapat faham dan 
mampu untuk melaksanakanya, jadi pendidikan karakter sendiri hampir sama misi nya dengan misi yang ada pada pendidikan akhlak dan pendidikan moral.

Adapun dalam kemendiknas sudah didefinisikan 18 karakter yang harus di tanamkan pada diri peserta didik sesuai yang sudah diambil bersumber dari agama, budaya,pancasila, dan tujuan dari pendidikan nasional. Yaitu.; 1.sikap religious. 2.mempuyai sifat jujur. 3. Mempuyai sifat toleransi, 4.mempuyai perilaku yang disiplin, 5. Kerja keras tidak mudah menyerah, 6. Mempuyai sifat kreatif, 7. Mempunyai sikap yang mandiri tidak bergantung pada orang lain, 8. Mempuyai sifat yang demokratis, 9.mempuyai rasa inggin tahu. 10. Mempunyai rasa kebangsaan yang kuat, 11.cinta tanah air, 12.dapat menghargai prestasi, 13.selalu bersahabat dan komunikatif, 14.selalu mencintai kedamaian, 15.mempuyai sifat gemar membaca, 16.peduli pada keadaan lingkungan ssekitar, 17.peduli sosial 18.mempunyai sifat tanggung jawab. ${ }^{15}$

Secara etimologis, tahap-tahap sendiri sering diartikan sebagai kata ulang, dari kata tahap sendiri yang berarti "bagian dari pertumbuhan (perkembangan), bagian dari sesuatu yang ada awal dan akhirnya, bagian dari sebuah urutan (menegak atau menyamping) tingkat" ${ }^{16}$ Dari beberapa kadungan arti alternatif yang ditawarkan diatas, tulisan ini menggunakan arti terakhir dalam penulisan nya, yaitu urutan bagian dari (menegak atau menyamping) tingkat. Pendidikan karakter sendiri menurut Doni Koesoema A. ialah "suatu dinamika kemampuan pengembangan yang sudah berkesinambungan dalam diri seorang manusia untuk mengadakan suatu internalisasi nilai sehingga dapat menghasilkan disposisi stabil dan aktif dalam suatu individu itu sendiri." Akan tetapi Di sisi lain, beliau juga

15 Heri Supranoto, 'Karakter Bangsa Pada Intinya Bertujuan', Jurnal Pendidikan Ekonomi UM Metro 3, no. 1 (2015): 36-49.

16 Nomor Ki, 'Tahap-Tahap Pendidikan Karakter Dalam Pemikiran Ki Ageng Suryomentaram Dan Relevansinya Dengan Pendidikan Akhlak Islam' I (2012): 187, https://doi.org/10.14421/jpi.2012.12.183-201. 
menambahkan bahwa pendidikan karakter itu sendiri juga melibatkan di dalamnya berbagai macam komposisi nilai, seperti nilai moral, nilai agama, nilai kewarganegaraan, dan nilai-nilai umum. di dalamnya juga termasuk sebuah tahap-tahap pendidikan karakter.

Setiap tahap sendiri juga memiliki nilai-nilai tertentu. Nilai sendiri ialah menurut Steeman dalam Sjarkawi, yaitu sesuatu yang dijunjung tinggi yang menjiwai dan dapat mewarnai tindakan seseorang. ${ }^{17}$ Adapun kriteria nilai dalam pendidikan karakter di sekolah ialah, menurut Doni Koesoema A menggemukakan, ada 8 macam kreteria nilai pendidikan karakter di sekolah yaitu: nilai cinta tanah air, nilai keutamaan, nilai kesatuan, keindahan, nilai demokrasi, nilai kerja, menghidupi nilai moral, dan nilai-nilai kemanusiaan.selain itu, pengertian karakter sendiri menurut Suyanto memiliki sembilan pilar (yang berasal dari nilai-nilai luhur universal), yaitu: karakter cinta Tuhan dan segenap ciptaan-Nya;tanggung jawab dalam kemandirian;amanah dan jujur; diplomatis;santun dan hormat; dermawan, gotong royong dan tolong menolong terhadap sesamat atau dapat diartikan sebuah kerjasama;pekerja keras dan mandiri; kepemimpinan dan keadilan; baik dan rendah hati; dan mempuyai karakter yang toleransi, cinta kedamaian, dan kesatuan. ${ }^{18}$

\section{Perencanaan, Implementasi, dan Evaluasi Pendidikan Karakter di Sekolah}

Pendidikan karakter di sekolah sendiri sangatlah terkait dengan suatu pengelolaan dan manajemen yang ada di sekolah. Karena Pengelolaan yang dimaksud disini yaitu bagaimana suatu lembaga pendidikan karakter dapat direncanakan (planning), dikendalikan (evaluation), dan dilaksanakan (actuating) terdapat dalam kegiatan-kegiatan pendidikan di sekolah yang sudah memadai. Pengelolaan tersebut diantaranya ialah seperti nilai-nilai yang perlu ditanamkan, pembelajaran, pembelajaran, pendidikan dan penilaian, serta komponen dan ketenaga kependidikan yang sudah terkait

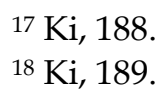


didalam nya. Dengan demikian pengelolaan yang ada di lembaga pendidikan (sekolah) dapat merupakan salah satu menjadi sebuah media yang efektif dalam mengaplikasikanya di dalam pendidikan karakter di sekolah. Secara terperinci dapat disimpulkan bahwa beberapa komponen yang sudah direncanakan dapat dikendalikan sehingga dapat dilaksakanya pengelolaan tersebut dan dapat dijabarkan sebagai berikut.:

Perencanaan berasal dari kata rencana ialah suatu rencana atau cara untuk membuat kegiatan yang memuaskan dan dapat berjalan dengan lancar, serta disertai dengan langkah yang antisipatif guna agar dapat memperkecil kesenjangan yang terjadi agar kegiatan tersebut dapat mencapai tujuan yang telah ditetapkan sesuai harapan.

Perencanaan itu sendiri merupakan keseluruhan dari suatu proses pemikiran yang menentukan penentuan semua aktivitas yang akan dilaksanakan pada masa yang akan datang dalam rangka mencapai tujuan. Cunningham yang dikutip Veithzal Rivai beliau menambahkan definisi nya tetang arti perencanaan ialah menghubungkan beberapa ilmu pengetahuan,imajinasi,fakta dan menyeleksi berbagai asumsi untuk masa yang akan datang agar dapat mencapai tujuan menvisualisasi dan memformulasi hasil yang sesuai diinginkan, beberapa kegiatan yang diperlukan, dan perilaku dalam batas-batas yang dapat diterima yang akan digunakan dalam penyelesaian.

Perencanaan sendiri menekankan pada suatu usaha menyeleksi yang menghubungkan sesuatu dengan kepentingan masa yang akan datang serta usaha untuk mencapainya. Apa wujud yang akan datang itu dan bagaimana usaha untuk mencapainya merupakan perencanaan.

Penekanan Perencanaan kepada usaha disini ialah kesejangan mengisi antara keadaan sekarang dengan keadaan yang akan datang dapat disesuaikan dengan apa yang di cita-citakan, seperti untuk menghilangkan suatu jarak antara keadaan sekarang dengan keadaan mendatang yang 
seperti yang diinginkan. Adapun Beberapa hal yang perlu dilakukan dalam tahap perencanaan pendidikan karakter disini ialah:

1) untuk Mengidentifikasi suatu jenis kegiatan yang ada di sekolah agar nantinya dapat terealisasi nya pendidikan karakter yang sesuai dan bisa dikuasai (difahami), selain itu juga peserta didik agar dapat merealisasikan nya dalam kehidupan sehari-hari. Agar dengan adanya program pendidikan karakter yang ada di sekolah, dengan begitu,peserta didik dapat merealisasikanya melalui tiga program kelompok kegiatan,seperti: saat pembelajaran berlangsung peserta didik dapat terpadu dengan mata pelajaran, peserta didik dapat terpadu dengan manajemen sekolah; dan lebih tersusun melalui kegiatan ekstra kurikuler.

2). Untuk setiap jenis kegiatan yang ada di sekolah Perlu adanya Pengembangan materi pembelajaran di sekolah

3). Perlu Adanya Mengembangkan pelaksanaan kegiatan dan adanya rancangan di setiap kegiatan yang ada di sekolah, seperti materi yang akan di ajarkan, guru/fasilitator,pendekatan saat pelaksanaan,tujuan,fasilitas yang penunjang kegiatan di sekolah,jadwal, evalusi agar dapat mengetahui dimana kekurangan nya supaya dapat diperbaiki dalam pelaksanaan selanjut nya.

4). Menyiapkan fasilitas pendukung untuk pelaksanaan program pembentukan karakter yang ada di sekolah

Selain itu Perencanaan kegiatan pendidikan karakter, program yang ada di sekolah juga mengacu pada jenis-jenis kegiatan nya, yang memuat beberapa unsur-unsur, seperti: Tujuan, pelaksanaan kegiatan dan termasuk pihak-pihak yang terkait di dalam nya Sasaran kegiatan,mekanisme yang ada, Substansi kegiatan, Keorganisasian di sekolah, Waktu dan Tempat, serta fasilitas pendukung yang ada di dalamnya.

Adapun beberapa perencanaan pendidikan karakter di sekolah RPP (Rencana Pelaksanaan Pembelajaran) juga termasuk bagian dari perencanaan pendidikan karakter yang ada di sekolah, di mana yang merupakan rencana 
jangka pendek untuk memproyeksikan serta memperkirakan bagaimana karakter yang akan ditanamkan terhadap peserta didik dalam pembelajaran. Dengan begitu adanya RPP yang berkarakter merupakan salah satu upaya untuk memperkirakan bagaimana tindakan yang harus dilaksanakan dalam kegiatan saat pembelajaran berlangsung untuk membina,membentuk, dan mengembangkan karakter peserta didik, agar sesuai dengan standar kompetensi dan kompetensi dasar (SK-KD) yang ada dan sesuai harapan. Oleh karena itu Perencanan pembelajaran perlu dikembangkan dan di tingkatkan agar dapat mengkoordinasikan karakter peserta didik yang akan dibentuk dengan kompetensi dasar,idikator hasil, materi standar, dan penilaian. Kompetensi dasar disini berfungsi untuk mengembangkan karakter yang ada dalam peserta didik, materi standar berfungsi untuk memaknai dan memadukan kompetensi dasar dengan berkarakter peserta didik, indikator hasil belajar berfungsi untuk menunjukkan sebuah keberhasilan pembentukan karakter peserta didik, sedangkan penilaian sendiri berfungsi untuk mengukur pembentukan karakter dalam setiap kompetensi dasar, agar dapat menentukan tindakan yang harus dilaksanakan pendidik (guru) apabila karakter yang telah ditentukan belum terbentuk atau belum tercapai.

Dari beberapa unsur perencanaan yang sudah di kemukakan di atas, maka dapat ditarik kesimpulan bahwa suatu perencanaan bukan hanya saja sebuah harapan yang ada dalam angan-angan dan bersifat khayalan dan tersimpan dalam benak seseorang, akan tetapi sebuah harapan dan anganangan serta langkah-langkah bagaimana yang harus dilaksanakan untuk mencapai tersebut,dan dideskripsikan secara jelas dalam suatu bentuk dokumen yang tertulis, sehingga nantinya dokumen tersebut dapat dijadikan sebuah pedoman oleh setiap orang yang memerlukanya. ${ }^{19}$

19 Dosen Fakultas, Tarbiyah Dan, and Raden Fatah, 'Implementasi Pendidikan Karakter Di Sekolah', Tadrib: Jurnal Pendidikan Agama Islam 1, no. 1 (2017): 118-36. 


\section{Membentuk Karakter Akhlak Peserta Didik}

Membentuk karakter akhlak peserta didik sangatlah penting, karena sudah banyak sekali masyarakat awam beranggapan bahwa pendidikan di Indonesia telah gagal, baik dari jenjang menengah dan tinggi, itu semua dikarenakan maraknya pelajar yang sangat minim akhlak atau sopan santun. Seperti kurang memiliki sikap kesantunan baik di sekolah,rumah dan di masyarakat.

Tetapi tidak bisa dipungkiri bahwa krisis nya pendidikan karakter akhlak peserta didik tidaklah hanya berpacu pada linngkungan sekolah saja akan tetapi lingkungan keluarga, masyarakat dan teman juga sangat mempengaruhi, oleh sebab itu untuk mengatasi minimnya karakter akhlak peserta didik yang baik tidak bisa memadai jika dilakukan hanya dilingkungkan sekolah saja, akan tetapi kita juga harus memperbaiki krisis moral,akhlak,dalam masyarakat luas, dalam lingkungan keluarga, dan lingkungan sekitar lainya.

Meski demikian, sekolah bukan berarti tidak dapat memulai upaya untuk mengatasi krisis karakter akhlak dan moral pada peserta didik tersebut, setidaknya dengan dimulainya dilingkungan sekolah sendiri dapat menjadi titik pusat pada awal dari sebuah usaha penyembuhan krisis karakter akhlak, dan moral di masyarakat kita menyeluruh, walaupun dengan upaya itu belum dapat menyembuhkan semua krisis akan tetapi dengan di mulainya penanaman implementasi pendidikan karakter dalam membentuk akhlak peserta didik di selingkungan sekolah sudah satu langkah lebih baik, karena lingkungan sekolah memiliki posisi yang sangat strategis dalam lingkungan masyarakat itu sendiri. ${ }^{20}$

Jika diterapkan di sekolah untuk menanamkan implementassi pendidikan karakter dalam membentuk akhlak peserta didik yang lebih baik dapat dimulai dengan cara sebagai berikut.: 1. Melalui penguatan

20 A Azra, 'Pendidikan Akhlak Dan Budi Pekerti: Membangun Kembali Anak Bangsa', Jurnal Pendidikan Akhlak 20, no. 1 (2001): 25-29. 
pelaksanaan kurikulum, seperti yang sudah dikemukakan oleh Anita Lie menyatakan bahwa dalam membentuk karakter akhlak peserta didik tidak dapat berdiri sendiri akan tetapi harus diintegrasikan dengan kurikulum. Yang dimana harus jadi penguat kurikulum itu sendiri yang sudah ada sebelumnya, dengan cara mengimplementasikan nya dengan mata pelajaran dan keseharian peserta didik. Contoh. Seperti saat mata pelajaraan kesenian, falsafah budaya dan manfaat dari adanya budaya itu sendiri, yaitu peserta didik diajarkan dengan cara mengajak mengenal dan mempraktekkan beragam peninggalan seni budaya yang menjadi muatan lokal. ${ }^{21} 2$. Dengan mata pelajaran pendidikann agama islam (PAI) karena dengan mata pelajaran pai sebagai peran agama pendidikan islam dirasa sangat strategis untuk mewujudkan sebuah karakter peserta didik yang berkarakter akhlak dan budi pengerti yang baik. Dalam mata pelajaran Pendidikan agama islam (PAI) juga menjadi sebuah sarana transformasi norma dan nilai moral untuk membentuk sikap aspektif pada diri peserta didik, sebagai transformasi pengetahuan dalam membentuk aspek keagamaan (kognitif), dan dapat berperan sebagai aspek psikomotorik yaitu untuk pengendalian perilaku peserta didik sehingga dapat terciptanya sebuah kepribadian,budi pekerti yang seutuhnya. 223

Ligkungan sekolah, karena pendidikan karakter menekankan dari sebuah pembiasaan dan keteladanan maka dapat direalisasikan dengan cara melalui kegiatan-kegiatan yang kondusif dan serta dapat diberikanya tugas keilmuan lainya yang dari penciptaan lingkungan itu sendiri, sehingga peserta didik sendiri dapat mencontoh,menirukan dan melaksanakan apa yang sudah mereka dengar dengan cara melihat dan merasakan, sehingga dapat dikerjakan oleh peserta didik untuk dapat membentuk karakter dan

21 Sri Judiani, 'Implementasi Pendidikan Karakter Di Sekolah Dasar Melalui Penguatan Pelaksanaan Kurikulum', Jurnal Pendidikan Dan Kebudayaan 16, no. 9 (2010): 280, https://doi.org/10.24832/jpnk.v16i9.519.

22 Ainiyah, 'Pembentukan Karakter Melalui Pendidikan Agama Islam'. 
akhlak yang baik. Menurut Beberapa uraian diatas selain untuk dijadikannya sebuah keteladanan dan pembiasaan bagi peserta didik juga dapat dijadikan sebuah metode pendidikan yang utama, serta dapat menciptakan iklim dan budaya. Sehingga yang terpenting dapat menjadikan lingkungan pendidikan yang kondusif bagi peserta didik untuk membentuk karakter akhlak peserta didik.

Menurut Aushop karakter atau watak seseoraang dapat dibentuk oleh beberapa faktor, beberapa factor yang dapat membentuk karakter akhlak peserta didik baik factor internal dan eksternal ialah:

1. nilai yang ditanamkan sejak kecil

2. keteladanan yang mereka idolakan

3. sebuah pembiasaan yang baik

4. hadiah (ganjaran) dan hukuman, yang mereka perbuat

5. sebuah kebutuhan. ${ }^{23}$

Menurut W Wuryandari dalam penelitian nya di sekolah menengah muhammadiyah Yogyakarta bahwa untuk merealisasikan Implementasi pendidikan karakter dalam sekolah tersebut diawali dengan kegiatankegiatan pembiasaan, pembiasaan tersebut dilakukan oleh semua staf sekolah ( kepala sekolah,guru,staf TU Dll ), adapun beberapa strategi yang diterapkan guru di sekolah tersebut untuk mengimplementasikan pendidikan karakter kemandirian dalam membentuk akhlakk peserta didik ialah.: 1. Memberi tugas kepada peserta didik agar bisa memanfaatkan sumber belajar dari berbagai perpustakaan dan media sosial (internet) 2 . Mengasah keterampilan peserta didik untuk berkreasi sekreatif mungkin menghias kelas sesuai kreatifitas masinng-masing individu. 3.dan pendidik (guru) membuat kontrak pembelajaran di setiap kelas. Strategi pembiasaan-

${ }^{23}$ Ramdhani, 'Lingkungan Pendidikan Dalam Implementasi Pendidikan Karakter'. 
pembiasaan tersebut dilakukan untuk menanamkan nilai-nilai karakter pada diri peserta didik. ${ }^{24}$

Implementasi pendidikan karakter dalam membentuk akhlak peserta diidik juga dapat direalisasikan melalui media edukasi IT (multimedia), seperti pengertian dari media sendiri yang dikemukakan oleh Gerlach \& Ely Rayandra Asyhar Bahwa media ialah tidak hanya mencakup alat-alat elektronik atau internet saja akan tetapi media sendiri mempunyai cakupan yang sangat luas, seperti manusia (pendidik/guru) juga bisa dikatakan sebagai media pembelajaran, dimana materi yang dapat membangun peserta didik untuk mampu membuat dan memperoleh suatu kondisi pengetahuan,keterampilan dan sikap akhlak peserta didik dengan baik. Media pembelajaran sendiri juga mencakup dari semua sumber yang dibutuhkan untuk berkomunikasi dalam pembelajaran, baik pembelajaran jarak jauh dan pembelajaran jarak dekat, sehinggs berupa perangkat keras ( hardware), seperti: proyektor,computer,leptop dan televisi. Adapun berupa perangkat lunak ( software) yang digunakan dalam perangkat keras tersebut.

Dari berbagai macam media diatas yaitu memiliki fungsi tersendiri untuk sebagai sumber belajar bagi peserta didik, yang menjadi sebagai penyalur, penghubung,dan penyampaian. DLL. ${ }^{25}$

Penilaian atau evaluasi sendiri ialah suatu usaha untuk memperoleh sebuah informasi secara berkala dan berkesinambungan secara menyeluruh tentang proses bagaimana hasil pertumbuhan, serta bagaimana perkembangan karakter itu sendiri yang sudah dicapai oleh peserta didik. Dengan Tujuan agar saat penilaian dilaksanakan pendidik (guru) dapat mengukur seberapa jauh peserta didik dapat menerapkan sesuai nilai-nilai

${ }^{24}$ Wuri Wuryandani et al., 'DI MUHAMMADIYAH BOARDING SCHOOL THE IMPLEMENTATION OF SELF-RELIANCE CHARACTER EDUCATION AT', n.d., 208-16.

${ }^{25}$ Farid Ahmadi, Yuli Witanto, and Ika Ratnaningrum, 'PENGEMBANGAN MEDIA EDUKASI “ MULTIMEDIA INDONESIAN CULTURE" ( MIC ) SEBAGAI PENGUATAN” 34, no. Mic (2017). 
yang sudah dirumuskan sebagai standar minimal yang sudah dikembangkan dan ditanamkan di sekolah, serta dihayati dan diamalkan agar dapat dipertahankan oleh peserta didik dalam kehidupan sehari-hari.

Penilaian pendidikan karakter disini lebih dititik beratkan pada keberhasilan peserta didik serta penerimaan nilai-nilai dalam prilaku dan sikap yang ada dalam peserta didik sendiri yang sudah sesuai dengan nilainilai karakter yang diterapkan serta diamalkan dalam kehidupan sehari-hari. Jenis penilaian ini berbentuk penilaian perilaku dan sikap, baik individu maupun kelompok.

Untuk mengukur tingkat keberhasilan pendidikan karakter disini ditingkat satuan pendidikan maka perlu dilaksanakan melalui berbagai program penilaian yang ada dengan membandingkan kondisi awal dengan pencapaian dalam waktu tertentu. Penilaian keberhasilan tersebut dapat dilaksanakan melalui beberapa hal sebagai berikut.

(1) Mengembangkan nilai-nilai indikator yang sudah ditetapkan dan disepakati.

(2) Membuat dan Menyusun beberapa instrumen penilaian.

(3) Melaksanakan pencatatan yang sesuai terhadap pencapaian indikator.

(4) Melaksanakan suatu analisis dan evaluasi.

(5) Melaksanakan tindak lanjut pelaksanaan.

Untuk melaksanakan penilaian pendidikan karakter pada peserta didik dapat dilaksanakan oleh semua pendidik (guru). Penilaian ini dapat dilaksanakan setiap saat, baik saat dalam jam pelajaran sedang brlangsung maupun diluar jam pelajaran, di dalam kelas maupun diluar kelas dengan cara pencatatan dan pengamatan oleh pendidik (guru). Karena Untuk berlangsung nya sebuah pelaksanaan pendidikan karakter yang ada di sekolah maka perlu dilakukan sebuah penilaian suatu keberhasilan dengan cara menggunakan indicator yang berupa perilaku semua warga sekolah dan 
kondisi sekolah yang diamati. Penilaian ini juga dapat dilaksanakan secara terus menerus dengan melalui berbagai strategi.

Instrumen ini juga termasuk penilaian yang dapat berupa lembar observasi, lembar portofolio, skala sikap, lembar check list, dan lembar pedoman wawancara. Informasi yang diperoleh bisa didapat dari berbagai teknik penilaian, kemudian bisa dianalisis oleh pendidik untuk memperoleh gambaran tentang karakter peserta didik tersebut. Kemudian gambaran keseluruhan tersebut dapat dilaporkan sebagai suplemen buku oleh wali kelas. Dan bisa Kerjasama dengan orang tua peserta didik. Agar dapat bisa mendapatkan hasil pendidikan yang baik dan sesuai, maka pihak sekolah perlu adanya kerjasama yang erat dan harmonis antara sekolah dan orang tua peserta didik. Dengan terjalinya kerjasama tersebut maka orang tua akan memperoleh:

> Pengalaman dan Pengetahuan dari guru dalam hal mendidik.

> Orang tua dapat Mengetahui kesulitan apa saja yang dihadapi oleh anak nya.

Orang tua dapat Mengetahui dan memantau tingkah laku anak nya selama disekolah, seperti apakah anak nya suka membolos, suka mengantuk, nakal dan sebagainya.

Sedangkan keutungan bagi guru, dengan adanya kerjasama antara guru dan oran tua tersebut guru akan memperoleh:

$>$ Berbagai Informasi-informasi dari orang tua dalam mengatasi kesulitan yang dihadapi anak didiknya.

> Bantuan dari orang tua dalam memberikan pendidikan sebagai anak didiknya di sekolah. ${ }^{26}$

$>$ Dapat terjalinya komunikasi yang baik antara orang tua dan guru.

${ }^{26}$ Fakultas, Dan, and Fatah, 'Implementasi Pendidikan Karakter Di Sekolah'. 


\section{KESIMPULAN}

Berdasarkan apa yang telah dijelaskan mengenai implementasi pendidikan karakter dalam Membentuk Akhlak Peserta Didik bahwasannya perlu dilakukan sejak usia dini peserta didik. Proses pembentukan karakter dan akhlak peserta didik melalui internalisasi di dalam lingkungan keluarga, institusionalisasi dalam lingkungan sekolah, dan eksternalisasi pada lingkungan masyarakat. Dalam pembentukan karakter dan akhlak peserta didik meliputi sejumlah tahapan yaitu perencanaan, implementasi dan evaluasi. Tahap Perencanaan dilakukan dengan adanya mengidentifikasi semua unsur yang berkaitan dengan pembentukan karakter peserta didik.

Setelah perencanaan terbentuk, tahapan selanjutnya implementasi. Dalam tahap implementasi, pihak yang terkait dalam pembentukan karakter dan akhlak peserta didik harus mengimplementasikan apa yang telah di buat pada tahap perencanaan. Dan terakhir tahap evaluasi, tahap evaluasi diperlukan untuk mengetahui seberapa tingkat keberhasilan tahap implementasi yang telah dilakukan serta mengecek kembali setiap kegiatan yang telah terjadi, apakah masih ada kesalahan ataukah sudah sesuai dengan apa yang direncanakan. Tahap evaluasi sangat penting dalam pembentukan karakter dan akhlak peserta didik karena memuat hasil seberapa jauh keberhasilan dalam pembentukan karakter peserta didik. Selain itu, tahap evaluasi bertujuan sebagai pondasi hasil dalam menentukan apa yang akan dilakukan tenaga kerja serta keluarga dalam pembentukan karakter dan akhlak peserta didik selanjutnya. Dalam ketiga tahapan tersebut jika dilakukan dengan maksimal tentunya akan mendapatkan hasil yang maksimal. Akan tetapi jika dalam pelaksanaan terdapat suatu kesalahan akan mempengaruhi tingkat keberhasilan dalam pembentukan karakter dan akhlak peserta didik 
Tafkir: Interdisciplinary Journal of Islamic Education

Vol.1, No.1, July 2020, , DOI:

Hal: 79-100, E-ISSN 2723-4975

\section{REFERENSI}

Abdurrahman, Nana Herdiana. 'Character Education in Islamic Boarding SchoolBased Sma Amanah'. Jurnal Pendidikan Islam 2, no. 2 (21 June 2016): 287-305. https://doi.org/10.15575/jpi.v2i2.791.

Ahmadi, Farid, Yuli Witanto, and Ika Ratnaningrum. 'PENGEMBANGAN MEDIA EDUKASI “ MULTIMEDIA INDONESIAN CULTURE ” ( MIC ) SEBAGAI PENGUATAN' 34, no. Mic (2017).

Ainiyah, Nur. 'Pembentukan Karakter Melalui Pendidikan Agama Islam' 13, no. 1 (2013): 25-38.

Amri, Muhammad, Saharuddin Saharuddin, and La Ode Ismail Ahmad. 'The Implementation of Islamic Education: The Process of Instilling Akhlakul Karimah (Noble Characters) for Madrasah Tsanawiyah Students'. Tadris: Jurnal Keguruan Dan Ilmu Tarbiyah 4, no. 1 (28 June 2019): 117-25. https://doi.org/10.24042/tadris.v4i1.4070.

Azra, A. 'Pendidikan Akhlak Dan Budi Pekerti: Membangun Kembali Anak Bangsa'. Jurnal Pendidikan Akhlak 20, no. 1 (2001): 25-29.

Baharun, Hasan, and Rohmatul Ummah. 'Strengthening Students' Character in Akhlaq Subject Through Problem Based Learning Model'. Tadris: Jurnal Keguruan Dan Ilmu Tarbiyah 3, no. 1 (29 June 2018): 21-30. https://doi.org/10.24042/tadris.v3i1.2205.

Fakultas, Dosen, Tarbiyah Dan, and Raden Fatah. 'Implementasi Pendidikan Karakter Di Sekolah'. Tadrib: Jurnal Pendidikan Agama Islam 1, no. 1 (2017): 118-36.

Implementasi, Mujahidah, and Teori Ekologi. 'IMPLEMENTASI TEORI EKOLOGI BRONFENBRENNER DALAM MEMBANGUN PENDIDIKAN KARAKTER YANG BERKUALITAS Mujahidah 1' IXX, no. 2 (2015): 171-85.

Judiani, Sri. 'Implementasi Pendidikan Karakter Di Sekolah Dasar Melalui Penguatan Pelaksanaan Kurikulum'. Jurnal Pendidikan Dan Kebudayaan 16, no. 9 (2010): 280. https:// doi.org/10.24832/jpnk.v16i9.519.

Ki, Nomor. 'Tahap-Tahap Pendidikan Karakter Dalam Pemikiran Ki Ageng Suryomentaram Dan Relevansinya Dengan Pendidikan Akhlak Islam' I (2012). https:// doi.org/10.14421/jpi.2012.12.183-201. 
Rony, Siti Ainun Jariyah

Ma`arif, Muhammad Anas. 'Pendidikan Islam Dan Tantangan Modernitas (Input, Proses Dan Output Pendidikan Di Madrasah)'. Nidhomul Haq : Jurnal Manajemen Pendidikan Islam 1, no. 2 (2016): 47-58. https://doi.org/10.31538/ndh.v1i2.1.

Ma`arif, Muhammad Anas, and Ibnu Rusydi. 'IMPLEMENTASI PENDIDIKAN HOLISTIK DI PONDOK PESANTREN AMANATUL UMMAH MOJOKERTO'. EDUKASI: Jurnal Penelitian Pendidikan Agama Dan Keagamaan 18, no. 1 (27 April 2020). https://doi.org/10.32729/edukasi.v18i1.598.

Ma'arif, Muhammad Anas, and Muhammad Husnur Rofiq. 'The Model of Character Teacher: Phenomenology at Daruttaqwa Gresik Islamic Boarding School'. Attarbiyah: Journal of Islamic Culture and Education 3, no. 2 (2 January 2019): 131-52. https:/ / doi.org/10.18326/attarbiyah.v3i2.131-152.

Maunah, Binti. 'Implementasi Pendidikan Karakter Dalam Pembentukan Kepribadian Holistik Siswa'. Jurnal Pendidikan Karakter, no. 1 (2016): 90-101. https://doi.org/10.21831/jpk.v0i1.8615.

Ramdhani, Muhammad Ali. 'Lingkungan Pendidikan Dalam Implementasi Pendidikan Karakter', 2013, 28-37.

Ridwan, Muhammad. 'Konsep Tarbiyah, Ta'lim Dan Ta'dib Dalam Al-Qur'an'. Nazhruna: Jurnal Pendidikan Islam 1, no. 1 (16 August 2018): 35-57. https://doi.org/10.31538/nzh.v1i1.41.

Rosyad, Ali Miftakhu, and Muhammad Anas Maarif. 'Paradigma Pendidikan Demokrasi Dan Pendidikan Islam Dalam Menghadapi Tantangan Globalisasi Di Indonesia'. Nazhruna: Jurnal Pendidikan Islam 3, no. 1 (7 February 2020): 75-99. https:// doi.org/10.31538/nzh.v3i1.491.

Supranoto, Heri. 'Karakter Bangsa Pada Intinya Bertujuan'. Jurnal Pendidikan Ekonomi UM Metro 3, no. 1 (2015): 36-49.

Workneh. 'IMPLEMENTASI PENDIDIKAN KARAKTER SISWA DI SMP ISLAM AL-AZHAR 18 KOTA SALATIGA'. Вестник Росздравнадзора 6 (2017): 5-9.

Wuryandani, Wuri, Fakultas Ilmu, Pendidikan Universitas, and Negeri Yogyakarta. ‘DI MUHAMMADIYAH BOARDING SCHOOL THE IMPLEMENTATION OF SELF-RELIANCE CHARACTER EDUCATION AT', n.d., 208-16. 